Edvins Danovskis, Dr. iur.

University of Latvia, Latvia

\title{
CONCEPT OF FREEDOM OF EVALUATION IN LATVIAN ADMINISTRATIVE LAW
}

\begin{abstract}
Summary
The article presents a research on the understanding and use of the concept of freedom of evaluation in the Latvian administrative court judgments. It outlines the main elements of this concept, explains the limits of judicial review of decisions based on freedom of evaluation and summarises the areas in which the freedom of evaluation has been acknowledged by the courts.
\end{abstract}

Keywords: freedom of evaluation, separation of powers, judicial review

\section{Introduction}

One of the realms of the executive power in which administrative courts do not interfere in substance is the so-called freedom of evaluation (German der Baurteilungsspielraum, Latvian - novērtējuma brīvïba). The concept of freedom of evaluation in the Latvian legal system has been transplanted from the German legal system. The first article in which this concept has been explained was written by a leading Latvian lawyer Egils Levits in 2003, in which he mentioned the concept of freedom of evaluation as an exception to the principle that the courts are entitled to review all facts and questions of law. He explains that "the control in substance is not possible, when the evaluation given by the authority refers to unique, unrepeatable situation. Such instances occur in cases when an authority grants evaluation of a person in a unique situation (exams, assessment of compliance). In such instances, within certain boundaries there exist the freedom of evaluation which the court cannot control in substance."

In German Administrative Law, the concept of freedom of evaluation has been developed since the 1950s. Generally, it refers to a situation, where a legal provision contains a general clause, which has to be interpreted and applied by a body whose expertise and specific knowledge is crucial in evaluating the facts of the case and subsuming them to the contents of the legal provision. According to the German case law, the freedom of evaluation exists in the following areas:

1) decisions on exams of various kinds (evaluation in state exams etc.);

2) other decisions similar to exams, particularly in schools (admission to next class etc.);

Levits E. Generālklauzulas un iestādes (tiesas) rīcības brīvība (II) [General provisions and discretion of an institution (court) II]. Likums un Tiesibas [Law and Rights], No. 7(47), July 2003, p. 203 
3) evaluation of civil servants;

4) decisions adopted by various boards, if expert knowledge for representation of various interests is at the core of the decision (for instance, decision to grant access to stock exchange market from the Stock Exchange Commission);

5) decisions related to prognosis and risk assessment in areas like environmental law and economic law;

6) decisions where at the core of decision are predetermined goals and issues in the area of administrative and economic policies. ${ }^{2}$

The concept of freedom of evaluation in the case law of Latvian administrative courts has been used at least since 2009. However, no research has been made in the Latvian administrative law regarding the contents of this concept and the consistency of its use in the court judgments. The only recent explanation of this concept is included in the textbook of Administrative law: "In contrast to the discretionary power, the court usually can review the application of provision containing so-called indefinite legal terms. However, there are areas lacking a complete review of application of indefinite legal terms. Such cases include freedom of evaluation and not the discretionary power. Freedom of evaluation exists only if the application of the legal term demands specific knowledge in a certain area. The court usually reviews only whether an obvious error on significant procedural breaches has been committed." 3 Therefore, the purpose of this article is to outline the main elements of the concept of freedom of evaluation and identify problems of its application.

The data obtained for this research were collected from the search engine of government portal manas.tiesas.lv, where more than 300 judgments were found containing the phrase novêrtējuma brivīiba (freedom of evaluation). A general look at these judgments indicates that the concept has been used more frequently in the recent years. During the research, all the judgments in which the court has used the concept of freedom of evaluation in order to limit the scope of its review were analysed.

\section{Decisions regarding disability status and payments from the medical risk fund}

Most judgments using the concept of freedom of evaluation have been adopted regarding decisions of the State Medical Commission for the Assessment of Health Condition and Working Ability (hereinafter - the State Commission). The doctors of the State Commission are entitled to adopted decisions on disability. The Disability

Maurer H. Allgemeines Verwaltungsrecht. 17. Auflage, Verlag C.H. Beck, München, 2009, pp. 150-151; similar outlook: Peine F. J. Vācijas vispārīgās administratīvās tiesības [General administrative law of Germany]. $4^{\text {th }}$ revised edition. Vācijas Administratīvā procesa likums [Administrative Procedure Law of Germany]. Rīga: Tiesu namu aǵentūra, 2002, pp. 68-69.

3 Briede J., Danovskis E., Koval̦evska A. Administratīvās tiesības [Administrative Law]. Mācību grāmata. Rìga: Tiesu namu aǵentūra, 2016, p. 34. 
$\mathrm{Law}^{4}$ defines three groups of disability, ${ }^{5}$ and the main criteria for disability is the loss of ability to work determined in percent. In the case law, the claimants ask to determine that they correspond to a more severe disability group or object to conclusion of a doctor if it states that the claimant does not correspond to the criteria for disability.

The courts do not interfere with the medical observations and evaluations of the person's ability to work issued by doctors of the State Commission. The arguments used by courts to limit their competence are mainly based on the professional expertise necessary to adopt the decision and therefore a natural obstacle to overrule the conclusions made by a professional body. For instance, the court has ruled that "only doctors of the State Commission are entitled to determine whether the claimant has such confinements of functioning that can be a basis for granting disability, likewise, only these doctors are entitled to discern, how severe the confinements are and what is the loss of ability to work in percent. The court [..] according to its competence can only review whether the conclusions made by doctors are not in obvious contradiction to the medical documentation and evidence in the case." The court has also stated that "evaluation of diagnosis, symptoms of ailment and condition of health is the competence of doctors and not of the courts." "Evaluation of confinements of functioning mainly is based on the professional experience of doctors of the State Commission which has accrued by comparing and assessing various similar cases. The court has no grounds to question this evaluation, since from the materials of the case and the application does not stem, that the evaluation of the experts is based on insufficient or not objective information."

In general, a court judgment in these cases mainly is composed from citations of legal provisions regulating evaluation and criteria of disability and contents of the medical documentation. This is the court's approach to reviewing whether the decision corresponds with procedural rules and whether it is not arbitrary. This is all that is required from the court in reviewing the legality of decisions passed by the State Commission. Although a claimant can submit evidence that he has an

4 Disability Law. Available at: https://likumi.lv/ta/en/en/id/211494-disability-law [last viewed October 5, 2019].

5 a) Group I disability, if the loss of ability to work is in the amount of $80-100$ percent, - very severe disability,

b) Group II disability, if the loss of ability to work is in the amount of 60-79 percent, - severe disability,

c) Group III disability, if the loss of ability to work is in the amount of 25-59 percent, - moderately expressed disability.

6 Judgment of Administrative Regional Court of 16 May 2019 in case No. A420204018, point 12. Available at: https://manas.tiesas.lv/eTiesasMvc/nolemumi/pdf/382965.pdf [last viewed October 5, 2019].

7 Judgment of Administrative Regional Court of 4 April 2016 in case No. A420328814, point 16. Available at: https://manas.tiesas.lv/eTiesasMvc/nolemumi/pdf/257777.pdf [last viewed October 5, 2019].

8 Judgment of Administrative District Court of 7 May 2019 in case No. A420316518, point 12. Available at: https://manas.tiesas.lv/eTiesasMvc/nolemumi/pdf/382280.pdf.pdf [last viewed October 5, 2019]. 
ailment, or ask for an expertise, the expertise can only prove facts instead of giving a legal evaluation of facts. Since the evaluation of facts in these cases demand specific knowledge and professional expertise, a judge has no authority to make medical statements and voice opinions of his own.

A similar approach is used in a rather recent category of cases concerning payments from the medical risk fund. The Law on the Rights of Patients ${ }^{9}$ provide that a patient is entitled to compensation for any harm (including moral harm) caused to his or her life or health, which has been caused by the medical practitioner working in the medical treatment institution through his or her acts or failure to act or caused by the conditions during medical treatment. Regulation of the Cabinet of Ministers provide that the Health Inspection determine the amount of harm in percent, taking into account various criteria (for instance, foreseeable course of disease, circumstances and environment in the hospital, quality of life and prognosis of life expectancy). It is evident that the legal regulation provides the Health Inspection with a considerable freedom of evaluation, because the total amount of harm is determined according to a variety of criteria, most of which require particular professional experience and knowledge. It is not surprising that in these cases the courts have also used the concept of freedom of evaluation in order to limit their scope of review. ${ }^{10}$

\section{Decisions regarding exams and assessment evaluations}

A classic example of freedom of evaluation both in Germany and Latvia is the evaluation in exams. In Germany, the exam law (Prüfungsrecht) exists as a particular branch of administrative law with several textbooks written on the subject. ${ }^{11}$ In Latvia, the case law regarding exams is just developing, but seems to be rather consistent. The courts have made judgments regarding examinations in universities, the Road Safety Directorate (exam for obtaining a driving licence), Data Protection Authority (exam of a data protection specialist), Insolvency Control Service (qualification exam of an administrator), Notary Council (qualification exam of a sworn notary), Association of Sworn Auditors (qualification exam of a sworn auditor). In all these cases, the courts have consistently ruled that they are not entitled to review the evaluation of exam. For instance, in a case regarding the exam for obtaining a driving license, the court has ruled that "the knowledge and skills to drive a vehicle is evaluated by an inspector in an exam. Therefore, the legal provision

9 Law on the Rights of Patients. Available at: https://likumi.lv/ta/en/en/id/203008-law-on-therights-of-patients [last viewed October 5, 2019].

10 For instance, Judgment of Administrative District Court of 17 April 2019 in case No. A420275718. Available at: https://manas.tiesas.lv/eTiesasMvc/nolemumi/pdf/380805.pdf [last viewed October 5, 2019]; Judgment of Administrative District Court of 5 March 2019 in case No. A420152218. Available at: https://manas.tiesas.lv/eTiesasMvc/nolemumi/pdf/377022.pdf [last viewed October 5, 2019].

11 For instance, Niehues N., Fischer E., Jeremias C. Prüfungsrecht. 7. Auflage, Verlag C. H. Beck, 2018; Zimmerling W., Brehm R. Prüfungsrecht: Verfahren - Vermeidbare Fehler - Rechtsschutz. Heymanns Verlag GmbH, 2007. 
grants inspector the freedom of evaluation. Judicial review of such an evaluation is limited. In case of freedom of evaluation, the court cannot review the conclusions of an authority in substance, but can merely review whether the authority has not committed an obvious error." 12 "When reviewing complaints about evaluations of exams, the competence of the courts is to review whether in the examination of procedure the principle of procedural fairness and prohibition of arbitrariness have been observed, as well as the principle of equality, that is, whether all persons had equal opportunities, equal circumstances, and whether the knowledge of all persons was evaluated in accordance with the same criteria. Therefore, the court cannot review the evaluation in substance." ${ }^{13}$

However, sometimes courts base their reasoning regarding freedom of evaluation on the premise that "an exam due to its unique situation cannot be repeated in court in order to review knowledge: it would be a new exam and not the review of knowledge demonstrated in the exam". ${ }^{14}$ This reasoning is outdated. Indeed, in oral exams and other exams that demand demonstration of practical skills (driving of a vehicle, etc.) the reason why the exam cannot be reviewed in substance is mainly practical - the exam cannot be reviewed just because the exam itself (demonstration of skills and knowledge) cannot be repeated and therefore there is no evidence of the demonstration. However, if the exam consists of written or otherwise recorded answers, the exam does not have to be repeated in order to review the knowledge. Hence, the reason behind the freedom of evaluation in exams is the fact that a particular knowledge and expertise is needed in order to determine whether the knowledge, skills and competencies of a person correspond to a certain level. Academic freedom in universities also is a consideration. The Supreme Court has stated that when the procedural rules of evaluation have been breached (insufficient motivation of evaluation and possible non-objectivity), the illegal situation can be remedied by repeatedly reviewing the written work. ${ }^{15}$

The courts have also acknowledged the freedom of evaluation in assessment processes in competition proceedings, insofar as the assessment is based on professional competence of the decision maker. For instance, an associate professor applied for a re-election. Despite the fact that he was the only contestant, the council of professors voted not to elect the contestant. The contestant submitted an

12 Judgment of Administrative Regional Court of 7 August 2018 in case No. A420356716, point 9. Available at: https://manas.tiesas.lv/eTiesasMvc/nolemumi/pdf/360434.pdf [last viewed October 5, 2019].

13 Judgment of Administrative District Court of 27 November 2012 in case No. A420645711, point 8. Available at: https://manas.tiesas.lv/eTiesasMvc/nolemumi/pdf/123183.pdf [last viewed October 5, 2019].

14 Levits E. Ģenerālklauzulas un iestādes (tiesas) rīcības brīvība (II) [General provisions and discretion of an institution (court) II]. Likums un Tiesibas [Law and Rights]. No. 7(47), July 2003, p. 203. See, for instance Judgment of Administrative District Court of 17 October 2017 in case No. A420163017, point 10. Available at: https://manas.tiesas.lv/eTiesasMvc/nolemumi/pdf/332244.pdf [last viewed October 5, 2019].

15 Judgment of the Department of Administrative Cases of the Supreme Court of 02 March 2012 in case No. A42915709, point 12. Available at: https://manas.tiesas.lv/eTiesasMvc/nolemumi/ pdf/120687.pdf [last viewed October 5, 2019]. 
application to the court. The court, inter alia, stated that "taking in consideration the autonomy of the university and the freedom of evaluation granted to the council of professors in deciding on the suitability of the contestant, the court acknowledges that the members of the council of professors are entitled to evaluate other criteria as well, unless they are arbitrary. The decision of the council of professors can be based on a vision of the council regarding reaching tasks and goals of the respective branch or subbranch of science, the previous and planned contribution of the contestant in reaching these goals, the attitude of the contestant towards his duties, in particular, if a person has been elected previously, personal observations and experiences in cooperation with the contestant. Therefore, taking into consideration the specifics of the election process, the post of the associate professor is not acquired by merely objective professional qualification criteria. [..] The court has no doubt regarding legality of the contested decision, for evaluation criteria have not been chosen arbitrarily, they are closely related with skills and tasks of an associate professor, and there are no obvious errors of evaluation." ${ }^{16}$

Similar cases include assessment made by various commissions in contests for distribution of public funding for various projects. For instance, in a case where a contestant had been denied the funding for a scientific project, because foreign experts had given to the contestant insufficient number of points to receive the funding, the court ruled that it "cannot review the assessment given by the foreign experts in substance, because the experts have the freedom of evaluation. The freedom of evaluation is based on the professional experience and knowledge of the expert. In case of the freedom of evaluation, the court only reviews whether an obvious error or significant procedural breach has been committed." 17 A similar reasoning has been given in other cases regarding assessment of commissions in competitions for funding. ${ }^{18}$ It is important to emphasize that courts do not review only those assessments which are based mainly on professional knowledge and where the criteria stipulated by legal provisions per se demand subjective insight and evaluation of the assessor. For instance, a criterion that a scientific project can contribute to further development of the science is of a purely subjective character and depends solely upon the judgment of an assessor. However, another criterion in the same competition - previous experience of project manager in other similar projects - can be objectively evaluated and therefore is fully reviewable by a court.

16 Judgment of Adminstrative District Court of 23 April 2019 in case No. A420308013, points 12 and 15. Available at: https://manas.tiesas.lv/eTiesasMvc/nolemumi/pdf/381062.pdf [last viewed October 5, 2019].

17 Judgment of Administrative Regional Court of 21 June 2016 in case No. A420231314, point 11. Available at: https://manas.tiesas.lv/eTiesasMvc/nolemumi/pdf/271003.pdf [last viewed October 5, 2019].

18 See, for instance Judgment of Administrative Regional Court of 4 June 2019 in case No. A420165318, point 16. Available at: https://manas.tiesas.lv/eTiesasMvc/nolemumi/pdf/384508.pdf [last viewed October 5, 2019]; Judgment of Administrative District Court of 9 May 2018 in case No. A420226217, point 8. Available at: https://manas.tiesas.lv/eTiesasMvc/nolemumi/pdf/352631.pdf [last viewed October 5, 2019]. 


\section{Assessment made by supervisory bodies}

The freedom of evaluation has been acknowledged by the courts in cases where an institution applies provisions which grant a power to interpret facts in such a manner that several interpretations are legitimate and well-grounded. Electronic Communications Law ${ }^{19}$ compels the Public Utilities Commission to ensure that "electronic communications merchants in mutual settlement of payments for the provision of the number portability service apply tariffs approximated to costs and the direct charges of the end-user if there are such shall not be an obstacle to the use of number portability service. The Regulator shall take the relevant decision for achievement of this objective." The Supreme Court has ruled that words "apply tariffs approximated to costs" and "obstacle to the use of number portability service" confers to the Commission the freedom of evaluation. The Supreme Court based its conclusions mainly on the fact that the provisions are very abstract and that the Court of the European Justice has also acknowledged "margin of appreciation" for the Commission. ${ }^{20}$ It appears that the provision contains only a general principle which even in one case cannot lead to a single mandatory result. Phrase "tariffs approximated to costs" include economic evaluation of various facts and therefore gives the Commission a significant freedom to decide on methods to be implemented and facts to be taken into account.

Another example of freedom of evaluation conferred upon a supervisory institution is the case where the Safety Police had published the annual report which stated that a particular person posed a threat to national security. The Supreme Court ruled that the Safety Police had a freedom of evaluation in assessing the risks which pose a threat to national security. ${ }^{21}$

In both cases, the legal provisions contain such general terms which cannot lead to a single legitimate outcome and which in essence entrust authorities with making assessments of facts not according to purely objective criteria, but by taking into account values, economic considerations and forecasts. Since such considerations can provide various outcomes, they are legal unless based on obviously erroneous judgments or made in breach of procedural requirements.

\section{Uncertainties and problems for future research}

Although the courts have been rather cautious in limiting the scrutiny of their review, it appears that there is one category of case law where use of the freedom

19 Electronic Communications Law. Available at: https://likumi.lv/ta/en/en/id/96611-electroniccommunications-law [last viewed October 13, 2019].

20 Judgment of the Department of Administrative Cases of the Supreme Court of 11 January 2013 in case No. A42680309, point 8. Available at: https://manas.tiesas.lv/eTiesasMvc/nolemumi/ pdf/123416.pdf [last viewed October 13, 2019].

21 Judgment of the Department of Administrative Cases of the Supreme Court of 31 May 2019 in case No. A420220916, point 10. Available at: https://manas.tiesas.lv/eTiesasMvc/nolemumi/ pdf/384111.pdf [last viewed October 13, 2019]. 
of evaluation concept seems to be misleading. Law "On Gambling and Lotteries"22 provides that the municipal council "shall decide on the permit to operate gambling on a case by case basis, if the operation of gambling on the particular premises does not create substantial impairment to the interests of the State and the residents of the respective administrative area." In 2012, the Supreme Court ruled that words "substantial impairment to the interests of the State and the residents of the respective administrative area" confer to the council the freedom of evaluation. ${ }^{23}$ However, since then the courts have identified several criteria used by municipal council as insufficient to deny a gambling permit. For instance, administrative courts have ruled that such argument as "significant intensity of pedestrians" in the respective area does not form sufficient grounds for denying a permit, unless the chances that a gambling house is visited by persons who did not originally want to enter it increases. Such considerations as nearby apartment houses or general negative attitude of residents towards gambling are not sufficient to maintain that a "substantial impairment" has been caused. ${ }^{24}$ The courts have also satisfied claims to issue gambling permits, therefore judging that there is no "substantial impairment". Consequently, in this category of cases, the court does scrutinize the arguments of the municipal council and quite rightly fills the content of the indefinite legal terms with its own merits. Hence, this is not a situation, where a special knowledge or professional experience would be mandatory in order to reach a decision. The conclusion that in this situation there is no need to talk about the freedom of evaluation corresponds to the German case law, where such indefinite legal terms as "important reasons" or "basis of public common interest" have not been acknowledged as conferring upon the authority the freedom of evaluation and thus limiting the scope of judicial review. ${ }^{25}$

If a legal provision confers upon an authority the freedom of evaluation, the courts still are entitled to make a thorough examination of all aspects of the case in order to check, whether the decision is not arbitrary (obviously, erroneous). If a court finds that the decision is arbitrary, the only remedy it can usually grant is declaring the decision illegal and repealing it. However, if a claimant has asked for a more favourable decision (for instance, a higher disability group), the court is generally not entitled to rule that the claimant should receive a higher disability group. In those cases, the court can merely oblige the authority to pass the decision once again. In general, such a solution prolongs the overall length of administrative proceeding and sometimes might prove ineffective.

22 On Gambling and Lotteries. Available at: https://likumi.lv/ta/en/en/id/122941-on-gambling-andlotteries [last viewed October 13, 2019].

23 Judgment of the Administrative Department of the Supreme Court of 14 December 2012 in case No. A42554407, point 8. Available at: https://manas.tiesas.lv/eTiesasMvc/nolemumi/pdf/123260. pdf [last viewed October 13, 2019].

24 See, for instance, Judgment of the Administrative District Court of 1 August 2019 in case No. A420295618, point 9. Available at: https://manas.tiesas.lv/eTiesasMvc/nolemumi/ pdf/388203.pdf [last viewed October 13, 2019].

25 Maurer H. Allgemeines Verwaltungsrecht. 17. Auflage, Verlag C. H. Beck, München, 2009, p. 149. 
Another aspect worthy of consideration is to what extent and in which areas the legislator can wilfully use legal provisions conferring upon the authorities the freedom of evaluation and thus limiting the scrutiny of the judicial review.

\section{Conclusions}

1. The freedom of evaluation is a concept used by administrative courts to limit the amount of scrutiny they use when reviewing the legality of administrative actions. The freedom of evaluation refers to a concept or phrase in a legal provision which, in order to apply it: 1) demands from the decision-maker specific knowledge, professional experience or personal insight in evaluating facts, making forecasts or assessing risks, and 2) allows various legitimate evaluations.

2. Administrative courts have acknowledged the freedom of evaluation in decisions regarding disability status, payments from the medical risk fund, examinations, assessment evaluations in competitions and several decisions made by regulatory or security authorities.

3. The concept of freedom of evaluation does not mean that a decision can be arbitrary. Even when the freedom of evaluation is acknowledged, the court is entitled to review all aspects of the decision in order to make sure that the decision is based only on considerations stemming from the legal provision.

\section{BIBLIOGRAPHY}

\section{Literature}

1. Briede J., Danovskis E., Kovaļevska A. Administratīvās tiesības [Administrative Rights]. Mācību grāmata [Textbook]. Rīga: Tiesu namu aǵentūra, 2016.

2. Levits E. G̦enerālklauzulas un iestādes (tiesas) rīcības brīvība (II) [General provisions and discretion of an institution (court) II]. Likums un Tiesïbas [Law and Rights], No. 7(47), July 2003.

3. Maurer H. Allgemeines Verwaltungsrecht. 17. Auflage, Verlag C. H. Beck, München, 2009.

4. Niehues N., Fischer E., Jeremias C. Prüfungsrecht. 7. Auflage, Verlag C.H. Beck, 2018.

5. Peine F. J. Vācijas vispārīgās administratīvās tiesības (ceturtais pārstrādātais izdevums) [General administrative law of Germany]. $4^{\text {th }}$ revised edition. Vācijas Administratīvā procesa likums [Administrative Procedure Law of Germany]. Rīga: Tiesu namu aǵentūra, 2002.

6. Zimmerling W., Brehm R. Prüfungsrecht: Verfahren - Vermeidbare Fehler - Rechtsschutz. Heymanns Verlag GmbH, 2007.

\section{Legislative acts}

1. Disability Law. Available at: https://likumi.lv/ta/en/en/id/211494-disability-law [last viewed October 5, 2019].

2. Electronic Communications Law. Available at: https://likumi.lv/ta/en/en/id/96611electronic-communications-law [last viewed October 13, 2019]. 
3. Law On Gambling and Lotteries. Available at: https://likumi.lv/ta/en/en/id/122941-ongambling-and-lotteries [last viewed October 13, 2019].

4. Law On the Rights of Patients. Available at: https://likumi.lv/ta/en/en/id/203008-law-onthe-rights-of-patients [last viewed October 5, 2019].

\section{Legal practice}

1. Judgment of the Department of Administrative Cases of the Supreme Court of 31 May 2019 in case No. A420220916. Available at: https://manas.tiesas.lv/eTiesasMvc/nolemumi/ pdf/384111.pdf [last viewed October 13, 2019].

2. Judgment of the Department of Administrative Cases of the Supreme Court of 11 January 2013 in case No. A42680309. Available at: https://manas.tiesas.lv/eTiesasMvc/nolemumi/ pdf/123416.pdf [last viewed October 13, 2019].

3. Judgment of the Department of Administrative Cases of the Supreme Court of 02 March 2012 in case No. A42915709. Available at: https://manas.tiesas.lv/eTiesasMvc/nolemumi/ pdf/120687.pdf [last viewed October 5, 2019].

4. Judgment of the Administrative Department of the Supreme Court of 14 December 2012 in case No. A42554407. Available at: https://manas.tiesas.lv/eTiesasMvc/nolemumi/ pdf/123260.pdf [last viewed October 13, 2019].

5. Judgment of Administrative Regional Court of 4 June 2019 in case No. A420165318. Available at: https://manas.tiesas.lv/eTiesasMvc/nolemumi/pdf/384508.pdf [last viewed October 5, 2019].

6. Judgment of Administrative Regional Court of 16 May 2019 in case No. A420204018. Available at: https://manas.tiesas.lv/eTiesasMvc/nolemumi/pdf/382965.pdf [last viewed October 5, 2019].

7. Judgment of Administrative Regional Court of 7 August 2018 in case No. A420356716. Available at: https://manas.tiesas.lv/eTiesasMvc/nolemumi/pdf/360434.pdf [last viewed October 5, 2019].

8. Judgment of Administrative Regional Court of 21 June 2016 in case No. A420231314. Available at: https://manas.tiesas.lv/eTiesasMvc/nolemumi/pdf/271003.pdf [last viewed October 5, 2019].

9. Judgment of Administrative Regional Court of 4 April 2016 in case No. A420328814. Available at: https://manas.tiesas.lv/eTiesasMvc/nolemumi/pdf/257777.pdf [last viewed October 5, 2019].

10. Judgment of the Administrative District Court of 1 August 2019 in case No. A420295618. Available at: https://manas.tiesas.lv/eTiesasMvc/nolemumi/pdf/388203.pdf [last viewed October 13, 2019].

11. Judgment of Administrative District Court of 7 May 2019 in case No. A420316518. Available at: https://manas.tiesas.lv/eTiesasMvc/nolemumi/pdf/382280.pdf.pdf [last viewed October 5, 2019].

12. Judgment of Administrative District Court of 17 April 2019 in case No. A420275718. Available at: https://manas.tiesas.lv/eTiesasMvc/nolemumi/pdf/380805.pdf [last viewed October 5, 2019].

13. Judgment of Administrative District Court of 23 April 2019 in case No. A420308013. Available at: https://manas.tiesas.lv/eTiesasMvc/nolemumi/pdf/381062.pdf [last viewed October 5, 2019]. 
14. Judgment of Administrative District Court of 5 March 2019 in case No. A420152218. Available at: https://manas.tiesas.lv/eTiesasMvc/nolemumi/pdf/377022.pdf [last viewed October 5, 2019].

15. Judgment of Administrative District Court of 9 May 2018 in case No. A420226217. Available at: https://manas.tiesas.lv/eTiesasMvc/nolemumi/pdf/352631.pdf [last viewed October 5, 2019].

16. Judgment of Administrative District Court of 17 October 2017 in case No. A420163017. Available at: https://manas.tiesas.lv/eTiesasMvc/nolemumi/pdf/332244.pdf [last viewed October 5, 2019].

17. Judgment of Administrative District Court of 27 November 2012 in case No. A420645711. Available at: https://manas.tiesas.lv/eTiesasMvc/nolemumi/pdf/123183.pdf [last viewed October 5, 2019]. 